Anna Tamara Devic*

The Archives of Vojvodina

Novi Sad

\section{Zsolt Lazar}

University of Novi Sad

Faculty of Philosophy
UDC: 78.01 Lanyi E.

161.225 .23

78.01 Csath G.

DOI: $10.19090 /$ gff.2020.1.191-207

Originalni naučni rad

\title{
ERNŐ LÁNYI IN MUSIC CRITIQUES BY GÉZA CSÁTH (1906-1912) ${ }^{* *}$
}

This paper presents the music critiques by Géza Csáth which are focused on the activity of Hungarian composer and music pedagogue Ernő Lányi in Subotica. The critiques were published in the daily newspapers Bácskai Hírlap in Subotica, and in Budapest, in Budapesti Napló, Polgár and A Hét, as well as in the literary journal Nyugat. In conclusion the authors estimated Lányi's real importance for the music life in Subotica, the artistic value of his compositions, as well as the question of the objectivity of Csáth's opinion about them.

Key words: Ernő Lányi, Géza Csáth, Subotica [Szabadka], cultural life, art song

The Hungarian composer Ernő Lányi (b. Ernő Langsfeld, 1861, Pest, Austro-Hungarian Empire - 1923, Subotica, the Kingdom of Serbs, Croats and Slovenes) is known in the Hungarian musicography for his achievements in the domains of songwriting and choral compositions, for his organization of the music life in Miskolc and in Subotica, as well as for his pedagogical work. However, no expert musicographical study of the life and work of this composer and music pedagogue has been written so far. ${ }^{1}$

Currently, the most informative biography of the composer is the one published by the translator and writer Márta Kovács Kenyeres within her monography Régi nóta, híres nóta (Kovács Kenyeres, 1976), in which, besides Ernő Lány, she writes about György Arnold and Ferenc Gaál, who were also important composers from Subotica. Besides the above mentioned biography, there is only

\footnotetext{
*ana.devic92@gmail.com

** The research was financially supported by Domus, a scholarship of the Hungarian Academy of Sciences.

${ }^{1}$ The authors are thankful to Attila Varga, Hungarian language teacher at the Music School in Subotica, for lending his collections of Ernő Lányi’s compositions, which greatly contributed to this paper.
} 
one more text at our disposal, Lányi Ernö Szabadkai Évei, levéltári dokumentumok, a collection of documents predominantly about Lányi's pedagogical work in Subotica, collected and published by the historian László Magyar (Magyar, 1996).

As mentioned, Ernő Lányi was considered an important composer and music pedagogue even during his life, and he owes his wider popularity to his compositions for male choirs, and to his modern folk and solo songs. Révai Nagy Lexikona from 1915 cites that he finished his music studies at Munich Conservatory, and that from 1878 he resided and worked as a music pedagogue in Hungary. Also, it cites that "he gained popularity across the country with his songs" and that "Lányi is one of the most important representatives and innovators of the Hungarian solo song" (Lányi Ernő, 1915: 493). It also says that his compositions for male choirs, "many of which were awarded", are also important (Lányi Ernő, 1915: 493). The entry in Új Idök Lexikona (1939) cites that Lányi was also “Koessler's (Budapest) pupil” (Lányi Ernő, 1939: 4110) and that he was a répétiteur in the Royal Hungarian Opera in Budapest at the time when Gustav Mahler was its director (during the season of 1889-1890). The entry's author points out that Lányi "executed a multifaceted conducting and pedagogical work in Miskolc and consequently in Subotica, and he earned great merit by organizing and improving the music life of the periphery" (Lányi Ernö, 1939: 4110). When pointing out Lányi's importance, this entry gives quite a realistic assessment of the composer, who was "a unique creator, (...) one of the most important representatives at the cusp between the hungarianized romanticism and folk trends" (Lányi Ernő, 1939: 4110).

Unlike general lexicons, ${ }^{3}$ music lexicons cite more details about Lányi's art and work. Thus, the entry in Hungária Zenei Lexikon (1945) points out that in various Hungarian cities where he worked as "a pedagogue and conductor of local

\footnotetext{
${ }^{2}$ This refers to the trend of establishing the $19^{\text {th }}$ century art in the traditional folk literature and folk music, which was an integral part of the fight for the national state and modern political organization of society of many European nations, including the Hungarian one.

${ }^{3}$ Postwar encyclopedias similarly assess Lányi's importance, but they also cite that he was the first to write solo songs based on the poetry of the modernist poet Endre Ady (Lányi Ernő, 1961: 312; Lányi Ernő, 1982: 30).
} 
choirs", Lányi "did far-reaching cultural work. In Subotica, he organized and conducted the Philharmonic Orchestra" (Lányi Ernő, 1945: 419). ${ }^{4}$

Despite the fact that his importance is noted, the real importance of Ernö Lányi still has not been adequately put in perspective. One of the ways to do it is to analyze music critiques and texts in the press of his time. This paper centers on Lányi's activity in Subotica ${ }^{5}$ - music periphery of Austro-Hungarian Empire, in which, after residing in Székesfehérvár, Eger and Miskolc, he lived from 1909 until his death, in 1923. When determining his importance, we opt for the analysis of critiques written by a Lányi's contemporary, the novelist, neuropsychiatrist and music critic Géza Csáth (1887-1919), who devoted 18 texts to Lányi's work in the period between 1906 and 1912. The majority of these critiques - seven - were published in the daily newspaper Budapesti Napló, five in Subotica daily newspaper Bácskai Hirlap, three in the modernist journal Nyugat, and one article each in the daily and weekly newspapers Budapesti Hírlap, A Polgár and A Hét, as well in the literary magazine Új Idők and literary journal Kritika. ${ }^{6}$

Soon after Ernő Lányi came to Subotica, Géza Csáth criticized the backwardness of the music life in his hometown. In the text "The State of Music in Subotica" $(6)^{7}$ he pointed out the grave shortcomings of the city church orchestra and demanded that the city make a complete reform of the existing orchestra, whose function had mostly been to perform music for church or theatre. Although the famous Hungarian composer Ernő Lányi was in the meantime appointed the orchestra's conductor and the principal of the Music School of Subotica - which was the first step towards the development of the music life in Subotica - Csáth thought that it was necessary to expand the orchestra by adding 7 or 8 new members, first and foremost wind-instrument players. The number of the orchestra members who were professional musicians increased only a few years later, but until then the orchestra was expanded by adding amateur musicians (see Kovač

\footnotetext{
${ }^{4}$ Other music lexicons also more or less repeat the previous information and point out the importance of his compositions for male choirs (Lányi Ernő, 1965: 413; Lányi Ernő, 1984: 389-390).

5 The official name of the city when it belonged to the Austro-Hungarian Empire (until 1918) was Szabadka and it appear under that name in Csáth's critiques and other Hungarian sources. In this article we use the Serbian name of the city - Subotica - because it refers to its present official name and position.

${ }^{6}$ Two texts were published two times in different newspapers.

${ }^{7}$ Numbers in parentheses refers to the complete information on articles given in Appendix.
} 
Kenjereš, 2008: 37). Nevertheless, even that kind of addition to the orchestra enabled Lányi to include far more demanding music pieces in the orchestra's concert repertoire.

Over time, Lányi transformed this orchestra into the Subotica Philharmonic Orchestra. Géza Csáth actively wrote music critiques until 1912, by which time the Philharmonic Orchestra had given 10 concerts, four of which Csáth attended. These critiques by Csáth are rather reports on concert evenings than critiques in the real sense of the term. However, they are important for us because they give us insight into the Philharmonic Orchestra's repertoire, based on which we can see that Lányi consciously chose popular classical pieces, which were supposed to attract audiences. By choosing this approach, Lányi obviously intended not only to educate the audiences but also to develop their music taste. In his critique published in the journal Budapesti Napló (10) Csáth informs us that at its first concert, which took place on February 12, 1908, the Philharmonic Orchestra performed Unfinished Symphony by Franz Schubert, the orchestral suite Peer Gynt by the Norwegian composer Edvard Grieg, and Mozart's Jupiter Symphony (Csáth, 2000: 364). The guest performer at the concert was the violinist Ilona Regéczy, ${ }^{8}$ who performed Beethoven's Romance in F-major, Tartini's Devil's Trill Sonata, and Scène da la csárda by Jenő Hubay. The concert was enormously successful, and Csáth said that Lányi had managed to build a true music life in Subotica in only one year. ${ }^{9}$

Based on Csáth's critiques, we can conclude that Lányi managed to maintain a high quality of concerts in the following years as well. The repertoire of the second concert (11), which took place on April $13^{\text {th }} 1908$, included Beethoven's Symphony No. 5, Schumann's Träumerei, Ranvé's ${ }^{10}$ Dans phantastique, Lányi's piece Ez a világ amilyen nagy... for male choir and orchestra, and the overture Bátori Mária by Ferenc Erkel. The soloists of the concert were the solo singer

\footnotetext{
${ }^{8}$ Ilona [von] Regéczy (?): a violinist; from the Budapest newspapers we have at our disposal we learn that she became famous when she was a child. After finishing her education in Budapest, she went on a European concert tour. She was often a guest performer in Spain and Sweden, where she also resided for a while (Regéczy Ilona Miskolczon nyaral, 1923: 4). She was also known for performing the works of Hungarian composers abroad: Magyar müvésznő és magyar szerző sikere Svédországban (1928: 244). On the success of her performances in Sweden see: Regéczy Ilona (1927: 36); Regéczy Ilona sikere Svédországban (1927: 282).

${ }^{9}$ It was not until the September 30, 1909, that the Municipality accepted the ordinance about the foundation of the orchestra (see Magyar, 1996: 14).

${ }^{10}$ Emil de Ranvé, a French composer.
} 
Rózsi Marschalkó ${ }^{11}$ and the violin professor Ferenc Koller. ${ }^{12}$ Marschalkó performed Handel's aria Largo from Xerses and Caro mio ben... by Giuseppe Giordani, a composition by Ödön Mihalovich and one by Jenő Hubay, as well as two songs by Lányi, while Ferenc Koller performed Saint-Saëns's Fantaisie. ${ }^{13}$

The next Csáth's report about the Philharmonic Orchestra concerns its $8^{\text {th }}$ concert (14) ${ }^{14}$ He cites only the authors whose works were performed at the concert (Tchaikovsky, Saint-Saëns, Grieg and Mendelssohn) without mentioning the names of the pieces, and he points out the obvious improvement in the music life of Subotica, which is directly linked to Lányi's activity in this city:

[T] he audiences pressed forward into the concert hall as into a cinema or a cabaret. This is certainly a cultural event. Those provincial ears noticed that there is a finer noise than gipsy music. A new music generation is growing up there, a disciplined and artistic generation that knows that true art begins beyond patriotic cacophony. Violin cases are emerging on empty streets. This is indeed surprising because Subotica is not only many kilometers away from Budapest, but there is also a vast plain that stands between them (...) This is the cultural fever that Ernő Lányi has brought into it. He who in his youth was a member of the Stockholm Theatre Orchestra, and later lived in Paris and Germany, out of noble passion and love of art is now pouring European culture into provincial Hungarian towns, into Eger and Miskolc, and into Subotica. (Csáth, 2000: 197-198)

As we have seen, in order to make the repertoire as diverse as possible and the quality of the performance as good as possible, Lányi often invited top soloists and guest performers to the Philharmonic Orchestra's concerts. Because of that, his activity relatively quickly outgrew the provincial frame. Besides Csáth, other notable persons from Budapest noticed the importance of the Subotica

${ }^{11}$ Rózsi Marschalkó (1890-1967), an opera singer and singing professor at the National Conservatoire in Budapest. She started her career of a concert singer in 1907, and she gave successful concerts in Budapest, Vienna and Berlin. From 1911 to 1929 she was a member of the Budapest Opera. She is one of the most important female performers of Wagner's music, and she was among the first to perform Bartók's and Kodály's compositions. See Marschalkó Rózsi (1981: 508).

${ }^{12}$ Ferenc Koller (1871-?): he was a teacher in music school in Kecskemét and Subotica, and from 1918 he was the principal of the Music School in Miskolc. See Koller Ferenc (1945: $383)$.

${ }^{13}$ It is not specified which one, but most likely it was Fantaisie for violin and harp in A major, Op. 124.

${ }^{14}$ However, the exact date when the concert took place is unknown. 
Philharmonic Orchestra. Within his critique "The News on the Philharmonic Orchestra" (16), Csáth cites an article by the aesthetician Artúr Bárdos ${ }^{15}$ in its entirey, in which he said that Subotica was the first purely Hungarian place in which Lányi had managed to create the necessary conditions for the performance of symphonic music in only three years. Although the orchestra gave only up to four concerts a year, continued Bárdos, the concert programs were well selected:

The artists from the capital [Budapest] and from abroad who visited Subotica mention the high quality of the programs with wonderment and surprise. An entire evening devoted to Beethoven with a performance of Pastorale has already taken place. The orchestra has also performed the First and the Fifth Symphony, and it is now preparing Eroica. The last concert of this kind took place last Wednesday in Subotica (the ninth in the last two and a half years), whose repertoire, among other things, included pieces by Haydn, Weber, Elgar and Beethoven. This fact will not just be mentioned in a short report, because, according to what we have heard, a Pest society for organizing concerts is thinking of inviting the entire Subotica Philharmonic Orchestra, together with its conductor, to perform during this or the next season. We would consider the realization of this plan a first-class cultural event. (according to Csáth, 2000: 200)

In the rest of the text, Csáth remarks that the achieved level also represents an obligation, and that there is nothing more dangerous for the Subotica Philharmonic Orchestra than stagnation. Precisely for that reason, "counting on the audiences' love and constant and encouraging interest, the Philharmonic society does not fear even the biggest challenges" (Csáth, 2000: 200). In accordance with that, in his critique published on December 11, 1910, Csáth informed the readers that the tenth philharmonic concert would take place on February 8, 1911, and that "a grandiose repertoire" was being prepared for that jubilee: Ünnepi nyitány by the Hungarian composer Ferenc Erkel, and Eroica, Beethoven's third symphony. The guest artist would be Stefi Geyer, ${ }^{16}$ a violinist of world renown, born in Budapest,

15 Artúr Henrik Bárdos (1882-1974), a Hungarian theater, radio and film director, playwright, dramaturge, aesthetician and publicist. The founder and editor in chief of the journal for performing arts Színjáték.

${ }^{16}$ Stefi Geyer (1888-1956), a notable violinist of international renown. She was a pupil of the eminent violinist Jenő Hubay at the Music Academy in Budapest. From 1911 to 1919 she lived in Vienna, and in 1920 she married the composer and pianist Walter Schulthess and settled in Zürich. She taught at the Zürich Conservatory. Within the project by the Zurich University of the Arts (Zürcher Hochschule der Künste, 2015-2019), an attempt was made to gather her entire legacy, see: http://www.zhdk.ch/forschungsprojekt/430817 
and she would perform Violin concerto by Goldmark, as well as a number of other compositions with piano accompaniment.

Csáth considered Lányi important not only because Lányi had founded the Subotica Philharmonic Orchestra and contributed to the development of the cultural life in Subotica, but also because of his work as a composer. In his critique from 1910 "The Overview of the Current State of the Hungarian Art Music" (15), Csáth says that Lányi is the most important representative of art songs in Hungary (Csáth, 2000: 102). However, the pieces that Lányi composed in his youth are simple "folk" i.e. urban traditional songs, influenced by Romani musicians - they represent the early period of his work. ${ }^{17}$ This period of Lányi's work belongs to the so-called third phase in the development of the Hungarian song, ${ }^{18}$ characteristic for the late $19^{\text {th }}$ century. According to the musicologist László Dobszay, during this phase composing songs was a very wide-spread activity among the members of the Hungarian gentry and intelligentsia:

There was almost no notary, doctor or officer who had not written a nostalgic song about his small village under the branches of black locust trees. The image of the world that arises from those songs - despite them being a heap of unthought-out clichés - is characteristic of a slightly sentimental mood of the time and of the tastes of a certain class which lacked the sense of reality. (Dobsay, 1998: 163) ${ }^{19}$

Their songs, says Dobszay, are characterized by an increase in melodic range, the use of disjointed melodic mostly minor scale sequences characteristic for Romantic harmonies, $\mathrm{AABA}$ or $\mathrm{AA}_{5} \mathrm{BA}$ form, rubato interpretation and its characteristic Romani way of accompaniment. The above-listed characteristics are

\footnotetext{
${ }^{17}$ In his youth, Lányi met the German composer Johannes Brahms and showed him a few of his compositions, but Brahms "did not express a positive opinion (...) about these works" (see Kovač Kenjereš, 2008: 34). A few of Lányi’s works can be found here: http://gramofononline.hu/search.php?sf=5\&q=Id.+L\%C3\%A1nyi+Ern\%C5\%91

18 The first phase was characterized by simpler songs which continued with the song tradition from the $18^{\text {th }}$ century, while the second phase, which started around 1840, was characterized by the influence of Romanticism and verbunk (hun: verbunkos; see Dobsay, 1998: 162-163).

19 According to Dobszay’s opinion, besides Lányi, this category includes Pista Dankó, Loránt Fráter, and Árpád Balázs (Dobsay, 1998: 163).
} 
also present in Lányi's compositions from this period, although a distinction can be made between songs in moderate tempo, with a mark for rubato interpretation (example 1), and the application of minor scales, and songs in a faster tempo, in major scales, while the remark concerning their interpretation often says to perform them "in a gipsy manner" (hun: czigányosan; example 2):

example 1: "Kántor uram ne bántsad" (Ernő Lányi, from 32 Eredeti magyar népdal [32 Original Hungarian Folksongs], by courtesy of Attila Varga)

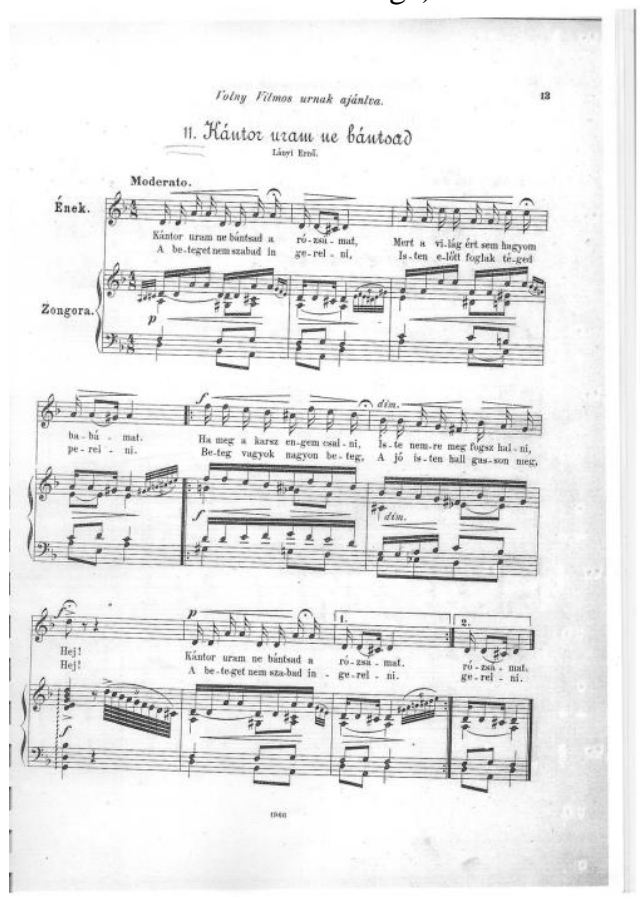

example 2: "Hej menyecske..." (Ernő Lányi, from 32 Eredeti magyar népdal [32 Original Hungarian Folksongs], by courtesy of Attila Varga)

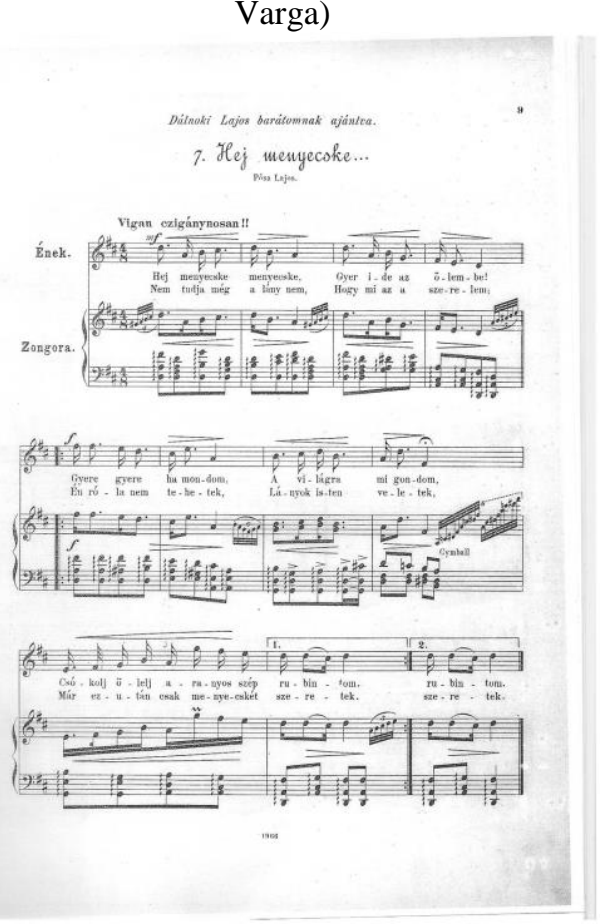

During the second period of his artistic work, Lányi composed art songs, ${ }^{20}$ which he wrote on poems by Hungarian poets Endre Ady, Dezső Kosztolányi, János Arany, József Kiss, and others. Csáth pointed out the importance of this shift in Lányi's opus - the shift from urban traditional songs to art songs (Csáth, 2000: 218) - in his critique "Ernő Lányi’s New Songs" (12), which he wrote on the occasion of the release of the collection of Lányi's songs op. 191-3, composed on

${ }^{20}$ In her book Márta Kovács Kenyeres uses the term 'concert songs' (koncertdalok, see Kenyeres Kovács, 1976: 99). 
Kosztolányi's verses. ${ }^{21}$ The critique was first published in Budapest, in the modernistic journal Nyugat, and a few days later in Bácskai Hírlap, in Subotica. Csáth says that these songs reflect the simplicity of form and the use of adequate harmonies, with which Lányi manages to create the atmosphere that the poet's verses require (example 3 ):

\section{example 3: “Üllöi-úti fák”, Op. 193}

(Ernő Lányi composition to the verses of Dezső Kosztolányi, from Három dal énekre és zongorára [Three Songs to Sing and Piano], by courtesy of Attila Varga)
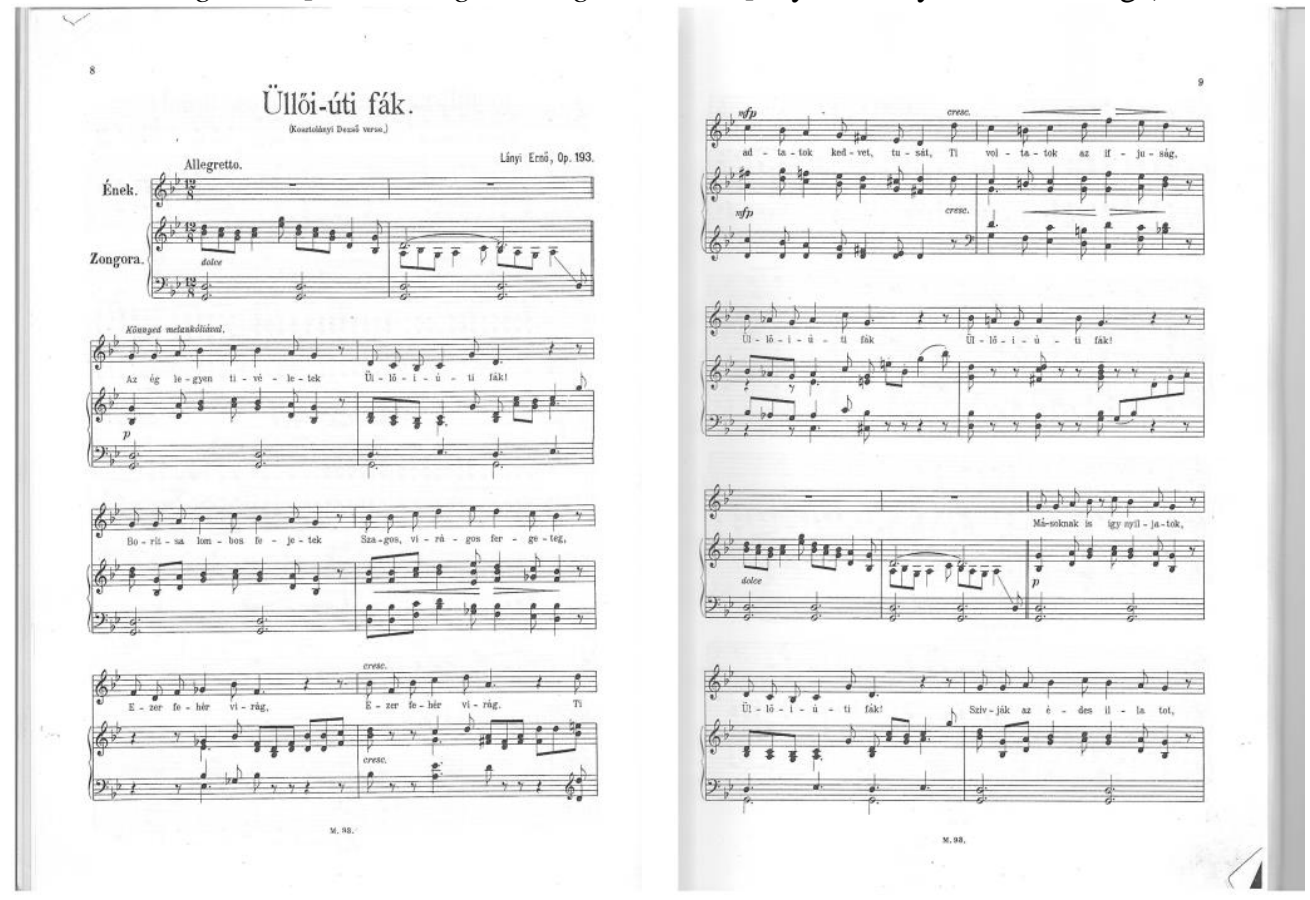

One of the key things to which Csáth draws the attention in his critique (13) is the fact that in his works Lányi manages to keep up with the times and changes (Csáth, 2000: 218). So, for example, while composing to the verses by the modernistic poet Endre Ady (example 4) - these compositions are included in Lányi's collection of songs Szeretném, ha szeretnének (Op. 207) - Lányi rationally uses modern, atonal harmonies:

\footnotetext{
21 http://slagermuzeum.network.hu/video/medgyaszay_vilma/medgyaszay_vilma_ulloi_ uti_fak
} 
These songs clearly prove that while composing them the composer did not experiment with modernistic elements (...) but that he deeply felt these poets' poetry and interpreted it honestly, using his own music language for piano and solo voice. He does not unnecessarily use altered chords and artificial foreign atonal melodies. He is, first and foremost, simple and clear. (Csáth, 2000: 231-232)

example 4: "Szeretném, hogyha szeretnének", Op. 207

(Ernő Lányi composition to the verses of Endre Ady, from Szeretném, ha szeretnének [I'd

Love to Be Loved], National Széchényi Library, Budapest)
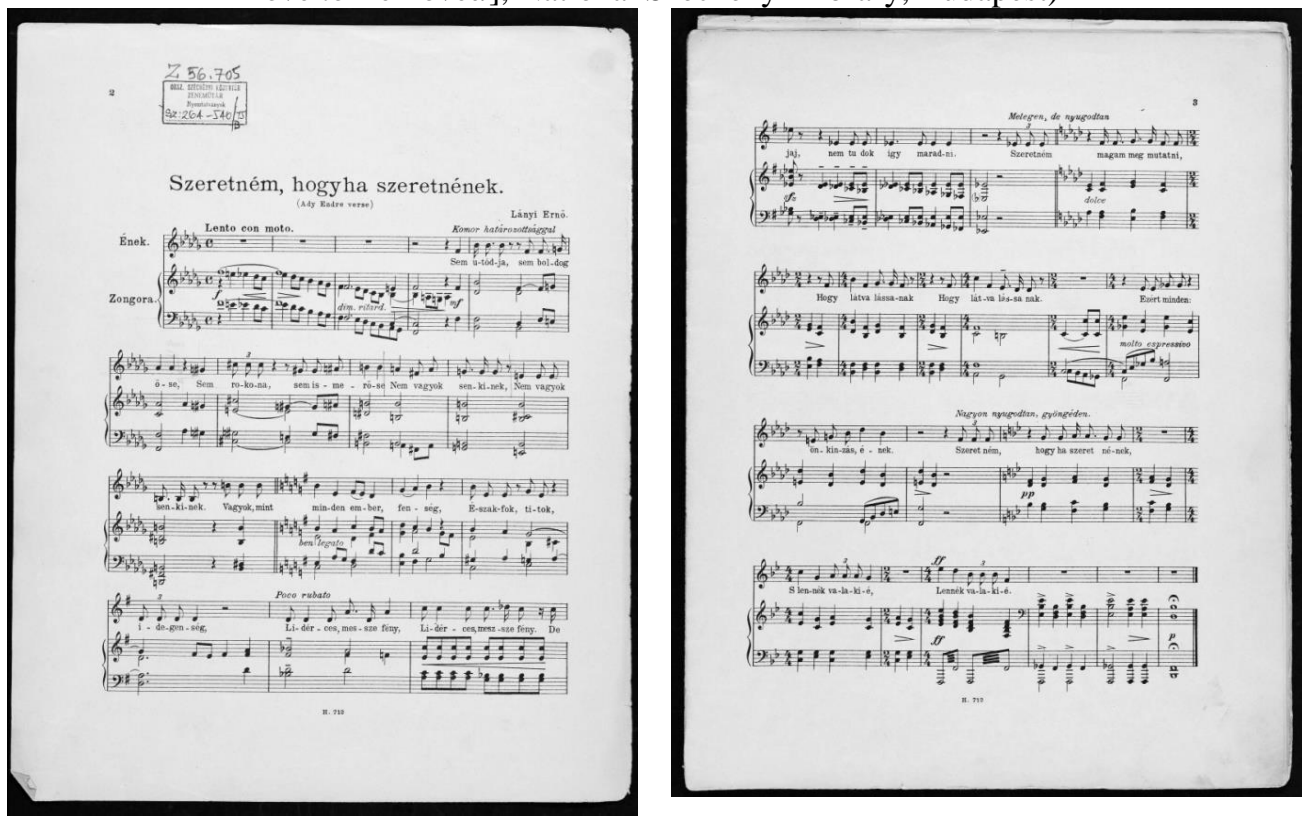

Csáth finds the upward curve of development, which is the most apparent in Lányi's songs, in his compositions for piano as well. He writes about it even in his first critique (1) at the end of 1906, published in Budapesti Napló and concerning two Lányi's collections for piano entitled Lírai hangulatok:

In these new collections too we can find Lányi the poet, whose every idea melts in a Hungarian melody, rhythm and harmony, but whose every line was created along the principles of the Western art. What Grieg did in his country, Lányi has been doing in the domain of the Hungarian music. I repeat, in the work before us his personality is represented in a new light. It is not some forced change of direction, but a further organic development of his style. No matter what we say, besides Ferenc Erkel, Lányi is our only composer who has style. (Csáth, 2000: 210) 
Besides the fact that this collection highlights Lányi’s innovation and good sense for choosing the right form for the compositions, Csáth points out that in them Lányi shows

"some music truths which, for example, Tchaikovsky and Grieg have already found in their countries. (...) And it is a great thing, because many people think that they are nowhere to be found in our country. (...) Therefore, Lányi's art has developed. Now, instead of pathetical-lyrical, he is searching for mystical-dramatic." (Csáth, 2000: 210)

In the journal Nyugat (18) Csáth also comments on the concert held in the Hungarian capital at which Lányi's works were performed for the first time. In Budapest, "where now" - says Csáth - "orchestra and theater music is flourishing more than ever", the audience understood Lányi's art made for house performances and a small circle of people (Csáth, 2000: 108). However, Csáth points out two problems with Lányi's music pieces: the first one is related to interpreters, and the other to the younger composers' attitude towards his works. The reason why solo singers rarely include Lányi's songs in their repertoire is because they cannot achieve a big effect on the audience when they sing them, while the foreign interpreters do not perform them because they do not speak Hungarian, although they could raise his songs to a certain artistic level. This is also the case with Lányi's piano pieces. For music interpreters, they are too simple and easy to interpret, they do not contain virtuosic passages and "special effects" (Csáth, 2000: 108). ${ }^{22}$ When younger musicians are concerned, notices Csáth, what they reproach Lányi is first and foremost the lack of inventiveness in the developing parts of compositions. However, Csáth does not agree with this opinion:

Which composer can say that while creating a new composition he has complete control over his work? Wasn't Bruckner limited in regard to form, or Brahms sensation for instrumentalization. And what about Bach's knowledge of human psychology? He disregarded the laws of apperception and its possibilities and endlessly knit melodic lines. In Lányi's art, we should find and highlight everything that it does contain, and not only list its flaws. (Csáth, 2000: 109)

\footnotetext{
${ }^{22}$ In his critiques Csáth also payed considerable attention to the interpretations of the most famous pianists of his time (see Dević, Lazar, 2017).
} 
When we follow the two main threads of Lányi's artistic work in the music critiques by Géza Csáth, 1) Ernő Lányi as the organizer of the music life in Subotica, and 2) Ernő Lányi as a composer, the following question arises: why did Csáth unreservedly support Lányi? One of the reasons must surely be the friendship between Lányi and Csáth's father, Dr. József Brenner Sr., which developed during Lányi's first stay in Subotica (1885-86), and which later grew into the friendship between their families. However, the favorable conditions for Lányi's employment in Subotica were created only after the death of Ferenc Gaál, the principal of the Music School, in December 1906. Then, Dr. György Sántha, speaking for himself and on the behalf of 51 members of the municipal board, suggested that Lányi, who was at the time the principal of the Music School in Miskolc (Hungary), be appointed as the new principal of the Music School and the church orchestra conductor (see Magyar, 1996: 8).

The importance of Lányi's activity in Subotica is reflected in the organization of the music life of the city. The proof of that is also Csáth's critique about the concert held on April 3, 1907 (3, 4), where Lányi was presented as the new principal of the Music School: "We could see what we had gained by appointing him. (...) The audience felt that all that was something new, and we too felt that this concert represented a cultural turning point in the social life of Subotica." (Csáth, 2000: 315) The pieces performed at the concert were: the overture from Weber's opera Der Freischütz, Lányi's composition for male choir Kertem alatt, and his melodrama Zách Klára, several scenes from Wagner's opera Lohengrin (which were performed with Csáth on violin and his father on piano), Beethoven's choral piece Die Himmel rühmen, a short humoresque by the English composer Samuel Coleridge-Taylor, and one of Lányi's orchestral composition, Kuruc induló. Csáth continues with exhilaration: "We who have until now watched the backwardness with pain, we salute the undeniable signs of progress with great joy, we salute beautiful results, we salute the future. We salute Ernő Lányi." (Csáth, 2000: 317) After that concert, Lányi intensively worked on the foundation of the Subotica Philharmonic Orchestra, and then on raising the level of the orchestra's quality, in which he was also supported by Csáth in his critiques $(6,10,11,14$, 16). ${ }^{23}$

${ }^{23}$ For more details about the Subotica Philharmonic Orchestra see Tibor Pekar (Pekar, 2008; Pekár, 2009). 
Concerning Lányi's compositions, Csáth compares them with Edvard Grieg's musical opus on several occasions. However, the musicologist Bertalan Fabó $^{24}$ thinks that Lányi's and similar songs from the territory of Hungary "are still folk songs, despite their richness, and compared to the German modern songs, they represent beginner's work" (Bertalan 1908: 457). Unlike the German art song (Lieder), which is "very developed and destined for music audience", at the time when Csáth praises Lányi the Hungarian song is still "folk song in the true sense of the word, because it is music food and soul food for millions" (Bertalan 1908: 458). Fabó's statement, which is also aimed at Lányi, can be only partially accepted, and only regarding the songs Lányi wrote in his youth, ${ }^{25}$ which were influenced by the Romani interpretations of Hungarian folk music. However, although Ernő Lányi's artistic scope is not big, his works undoubtedly represent an important link in the development of the Hungarian music. This especially applies to his songs, which evolved in an interesting way from modern folk songs over traditional urban songs into art solo songs. Lányi was probably inspired to compose solo songs closer to the standards of the European art music thanks to the constant contact with symphonic music, due his position of the conductor of the Philharmonic Orchestra in Subotica. This is corroborated by the fact that Lányi wrote two such collections only after coming to Subotica: collection of songs based on the texts by Dezső Kostolány (1907) and Endre Ady (1911). In that sense, the overall assessment given by Géza Csáth in the above mentioned critique on Lányi (18), published in the journal Nyugat, is more correct:

$\mathrm{He}$ is developing and he is seriously questioning himself; he is an honest composer to the marrow. His innovation is individual. (...) He is searching for a simple and for the simplest way of expression. In this regard as well, he is classically inclined. His songs are the first Hungarian songs with impeccable prosody. (Csáth, 2000: 109)

Csáth's opinion was also supported by a critique published a little bit later, in 1914, in the journal Zene in Budapest. On the occasion of the release of the new collection of Lányi's songs, the author states that "the national instinct in [Lányi's]

\footnotetext{
${ }^{24}$ Bertalan Fabó (1868-1920), a lawyer by vocation, but also a very influential music writer of his time.

${ }^{25}$ Lányi called his songs from this period traditional Hungarian songs, and he published several collections of them: 32 Traditional Hungarian Folk songs, 33 Traditional Hungarian Folk Songs, 84 Traditional Hungarian Folk Songs etc. See also Kovač Kenjereš (2008: 34).
} 
heart, through which Hungarian blood flows, has inspired absolutely pure means, from which, like from a crystal clear source, a brand-new phraseology of true Hungarian music flows" (S.E., 1914: 101). Also, the author says that Lányi's development has raised him to such a level that he can no longer indulge the tastes of the masses; now his art has a different goal, and that is to prepare and mark new directions in the domain of the Hungarian song. Thus, a few years after Csáth had stopped his intensive work as a critic, his opinion that some of Lányi's songs indeed reached the standard of European art music was confirmed. Csáth's views should be taken seriously, and even more so because he was the first to recognize the true importance of the artistic interpretations of Bartók's and Kodály's collections of traditional folk songs.

Anna Tamara Devic, Zsolt Lazar

ERNE LANJI U MUZIČKIM KRITIKAMA GEZE ČATA (1906-1912)

Rezime

U radu se predstavljaju i razmatraju napisi o mađarskom kompozitoru i muzičkom pedagogu Erneu Lanjiju, koje je Geza Čat objavljivao u subotičkim novinama Bácskai Hírlap, u budimpeštanskim novinama Budapesti Napló, Polgár i A Hét, kao i u časopisu Nyugat. Navedene muzičke kritike su značajne i zbog toga što pružaju uvid u razvoj muzičkog života Subotice u vreme kada je Erne Lanji postao direktor muzičke škole u ovom gradu. U centru pažnje je Lanjijev doprinos formiranju i razvoju subotičkog Filharmonijskog orkestra, kao i njegov značaj za razvoj kulturnog života u Subotici početkom 20. veka. Iz Čatovih kritika vidimo da je, zahvaljujući Lanjiju, subotička publika imala retku priliku da kontinuirano prati koncerte umetničke muzike, kao i da su na njenom repertoaru bila i neka od najzahtevnijih dela simfonijske muzike. Pored toga, detaljnije se razmatraju i Čatovi stavovi o kompozitorskoj delatnosti Erne Lanjija, a posebno njegova umetnička evolucija u domenu komponovanja pesama. U tom smislu posebno je značajan Lanjijev prelaz sa novokomponovanih narodnih na umetničke solo pesme, koje je komponovao na poeziju istaknutih mađarskih pesnika Endre Adija, Deže Kosztolanjija, Janoš Aranja i drugih, za koje je Čat procenio da pripadaju razvijenoj fazi mađarske umetničke muzike. U zaključku se iznosi ocena objektivnosti Čatovih stavova o Lanjijevom značaju za muzički život Subotice, kao i o umetničkoj vrednosti njegovih kompozicija.

Ključne reči: Geza Čat, Erne Lanji, Subotica, Budimpešta, kulturni život 


\section{BIBLIOGRAPHY:}

Csáth, G. (2000). A muzsika mesekertje. Szajbély, M. (ed.), Budapest: Magvető Könyvkiadó.

Dević, A. T. - Lazar, Zs. (2017). Sauer's, Godowsky's, and Backhaus's Budapest Recitals in the Reviews of Géza Csáth (1906-1912). Studia Musicologica, 58 (3-4), 399-414.

Dobszay, L. (1998). Magyar zenetörténet. Budapest: Mezőgazda Kiadó.

Fabó, B. (1908). A magyar népdal zenei fejlödése. Budapest: A Magyar tudományos akadémia kiadása.

Kelemen, É. (2015). Müvészetek vándora. A zeneszerző Csáth Géza. BudapestGyőr: OSZK-Magyar Kultúra Kiadó.

Kenyeres Kovács, M. (1976). Régi nóta, híres nóta... Szabadka: Életjel.

Koller Ferenc (1945). Hungária Zenei Lexikon, V. Lányi (ed.), Budapest: Hungária.

Kovač Kenjereš, M. (2008). Život i delo Ernea Lanjija. Rukovet, 7-8-9, 33-38.

Lányi Ernő (1915). Révai Nagy Lexikona Vol. 12. Budapest: Révai Testvérek Irodalmi Intézet Részvénytársaság.

Lányi Ernő (1939). Újj Idők Lexikona, Vol. 15-16. Budapest: Singer és Wolfner Irodalmi Intézet RT.

Lányi Ernő (1945). Hungária Zenei Lexikon. V. Lányi (ed.), Budapest: Hungária. Lányi Ernő (1961). Új Magyar Lexikon, Vol. 4. Budapest: Akadémiai Kiadó. Lányi Ernő (1965). Zenei lexikon, Vol. II. Budapest: Zenemükaidó Vállalat.

Lányi Ernő (1982). Magyar Életrajzi Lexikon, Vol. 2. Budapest: Akadémiai Kiadó.

Lányi Ernő (1984). Brockhaus Riemann Zenei lexikon, Vol. II. Budapest: Zenemúkiadó.

Magyar, L. (1996). Lányi Ernő Szabadkai évei - Levéltári dokumentumok. Szabadka: Életjel.

Magyar művésznő és magyar szerző sikere Svédországban (1928). A Zene, 12, 244.

Marschalkó Rózsi (1981). Magyar Életrajzi Lexikon Vol. 3. Budapest, 508.

Pekar, T. (2008). 100 godina Subotičke filharmonije: istorijat orkestarskog muziciranja u Subotici (1908-2008). Subotica: Grafoprodukt.

Pekár, T. (2009). A Szabadkai Filharmónia száz éve. Szabadka: Grafoprodukt.

Pekár, Tibor (2002). Szabadka zenei élete (1900-1918): adalékok a város zenei múltjának történetéhez. Szabadka: Szabadegyetem.

Regéczy Ilona (1927). Színházi Élet, 22, 36.

Regéczy Ilona Miskolczon nyaral (1923). Magyar Jövö, 192, 4.

Regéczy Ilona sikere Svédországban (1927). A Zene, 14, 282.

S. E. (1914). II Zenemüvek. Zene, 5, 101. 


\section{APPENDIX}

Music critiques by Géza Csáth about Ernő Lányi (1906-1912) 26

1. Lányi Ernő új kottái (New Compositions by Ernő Lányi), Budapesti Napló, December 25, 1906.

2. Lányi Ernő összegyüjtött művei (Ernő Lányi’s Collected Works), Budapesti Napló, January 30, 1907.

3. Hangverseny a színházban (Concert at the Theatre), Bácskai Hírlap, April 4, 1907.

4. Lányi Ernő Szabadkán (Ernő Lányi in Subotica), Budapesti Napló, April 7, 1907.

5. Érdekes új kották (Interesting New Compositions), Budapesti Napló, June 15, 1907.

6. Szabadka zenei állapotai (State of Music in Subotica), Bácskai Hírlap, June 19, 1907.

7. Jegyzetek a egri dalünnepröl (Notes on a Singing Gala in Eger), Budapesti Napló, August 20, 1907.

8. Az egri Dobó-ünnep és dalverseny, (Dobo Festival in Eger and a Singing Competition), Új Idők, August 25, 1907.

9. Lányi Ernő munkái (Ernő Lányi’s Works), Budapesti Napló, December 18, 1908.

10. Filharmónia hangverseny Szabadkán (The Philharmonic Orchestra's Concert in Subotica), Budapesti Napló, February 14, 1908.

11. Filharmonikus hangverseny (The Philharmonic Orchestra's Concert), Bácskai Hírlap, April 13, 1908.

12. Lányi Ernő új dalai (Ernő Lányi’s New Songs), Nyugat, February 1, 1909; Bácskai Hírlap, February 7, 1909.

13. Új kották (New Compositions), A Polgár, April 9, 1909.

14. Szabadkai Filharmonikusok (Subotica’s Philharmonic Musicians), A Hét, April 10, 1910.

15. Szemle a magyar muzsika jelenlegi állapotán (The Overview of the Current State of Hungarian Music), Kritika, November 1, 1910.

\footnotetext{
${ }^{26}$ The list is composed according to the bibliography assembled by Éva Kelemen (Kelemen, 2015: 161-258).
} 
16. Hírek a Filharmóniából (News on the Philharmonic Orchestra), Budapesti Hirlap, December 11, 1910.

17. Új kották. Lányi Ernő, Reinitz Béla, Kovács Sándor (New Compositions. Ernő Lányi, Béla Reinitz, Sándor Kovács), Nyugat, June 1, 1911; Bácskai Hírlap, June 8, 1911.

18. Lányi Ernő (Ernő Lányi), Nyugat, February 1, 1912. 